\title{
Different Ethical Perspectives Justifying Reasonings Behind a Person's Actions: A Case Study on a Private Institution in Malaysia
}

\author{
Diyana Kamarudin ${ }^{1}$, Haziman Zakaria², and Azizan Azit ${ }^{3}$ \\ 1,3 Faculty of Industrial Management,, Universiti Malaysia Pahang, 26300 Pahang, Malaysia. \\ ${ }^{2}$ Faculty of of Management, University College of Yayasan Pahang, Taman Gelora Campus, 25050 Pahang, Malaysia.
}

\begin{abstract}
Private institutions in Malaysia are bound to the Private Higher Institution Act 1996 which normally relies on corporate investments to sustain their operations. Data from the Department of statistic Malaysia indicates that there is a significant increment of gross output value in the education sector in Malaysia from RM 17.6 billion in 2017 compared to RM 15.2 billion in 2015 which reflects the business competencies in private institutions (Ministry of Education Malaysia, 2015). This research is a case study conducted at one of the private colleges in Kuantan, Pahang. The aim of this research is to analyze the ethical issues concerning business ethics using semi structure interview method with college staff and students. The interviews were recorded and transcribed. Each case was analyzed individually, discussed and linked to the business ethics concept and ethical principle. This research aims to create awareness on good moral value and business ethics that can be practiced in the private education sector in Malaysia..
\end{abstract}

ARTICLE HISTORY

Received: 12-06-2020

Accepted: $26-07-2020$

\section{KEYWORDS}

Business Ethics, Private Institution, Ethical Principle.

\section{INTRODUCTION}

Higher Education Institutions (HEI) in Malaysia can be divided into two categories which are public and private higher education institutions. Public Higher Education Institutions refers to any public university and colleges that are funded by the government. These institutions are considered to be under the Ministry of Education. Institutions such as these help provide quality education to Malaysian student. These institutions and are categorized into 3 major groups which are (i) Research Universities, (ii)Focused Universities and (iii) Comprehensive Universities (Ministry of Education Malaysia, 2015).

Private Higher Education Institutions refers to universities and colleges that are privately owned and these insitutions usually rely on fundings from corporate investment, alumni and student fees according to the Private Higher Educational Institutions Act 1996 to help sustain their operations (Laws of Malaysia, 2015). Some of these institutions' establishment work together with legitimate remote colleges to mutually grant degree capabilities.

All private-subsidized advanced education organizations (IPTS) go under the locale of the Ministry of Education and include Private Universities which grant their own degree capabilities, recognitions and establishment thinks about, Private University-Colleges which grant their very own degree capabilities, confirmations and establishment examines, Foreign University Branch Campuses which grant their very own degree capabilities, confirmations and establishment studies and Private Colleges which grant their very own capabilities at recognition and authentication levels just as $3+0$ degrees, split-degrees and instructional exercise support for expert capabilities (Wan, Sirat, \& Razak, 2018). With such significant administration capabilities and freedom, the level of ethical practice is debatable. We often hear about ethical misconduct cases related to a private institution in media but usually the outcome or solution typically still a long way to go. Berita Harian covered a story on five cases involve IPTS regarding PTPTN fraud cases between 2016-2018 which has not been settled yet until now (Mohd Azrone Sarabatin; Mohd Iskandar Ibrahim: Mohd Nasaruddin Parzi, 2019). An article from the Harian Metro dated $25^{\text {th }}$ March 2019 also wrote about this issue. A private higher education institution or IPTS embezzeled money from the Perbadanan Tabung Pendidikan Tinggi Nasional or PTPTN. The insittution filed claims for 6 semesters, when in reality there are only 5 semesters in the program (Harian Metro, 2019). In a nutshell, misconduct behaviour may happen or experienced by student and staff who are in a private institution.

Business ethics is a study of moral right and wrong that focuses on an organization. When describing what to be covered within an organization in studying business ethics, there a lot of issues that can be covered. Normally, business ethics studies will be divided into three main categories which are systematic issue, corporate issue and individual issue. On the other hand, for this study, the issue will be selected according to four different categories based on moral and legal right or wrong. The ethical framework is build based on Fisher and Lovell Ethical Framework that divided a case study into four case studies show in Figure 1(Lovell \& Fisher, 2010). 


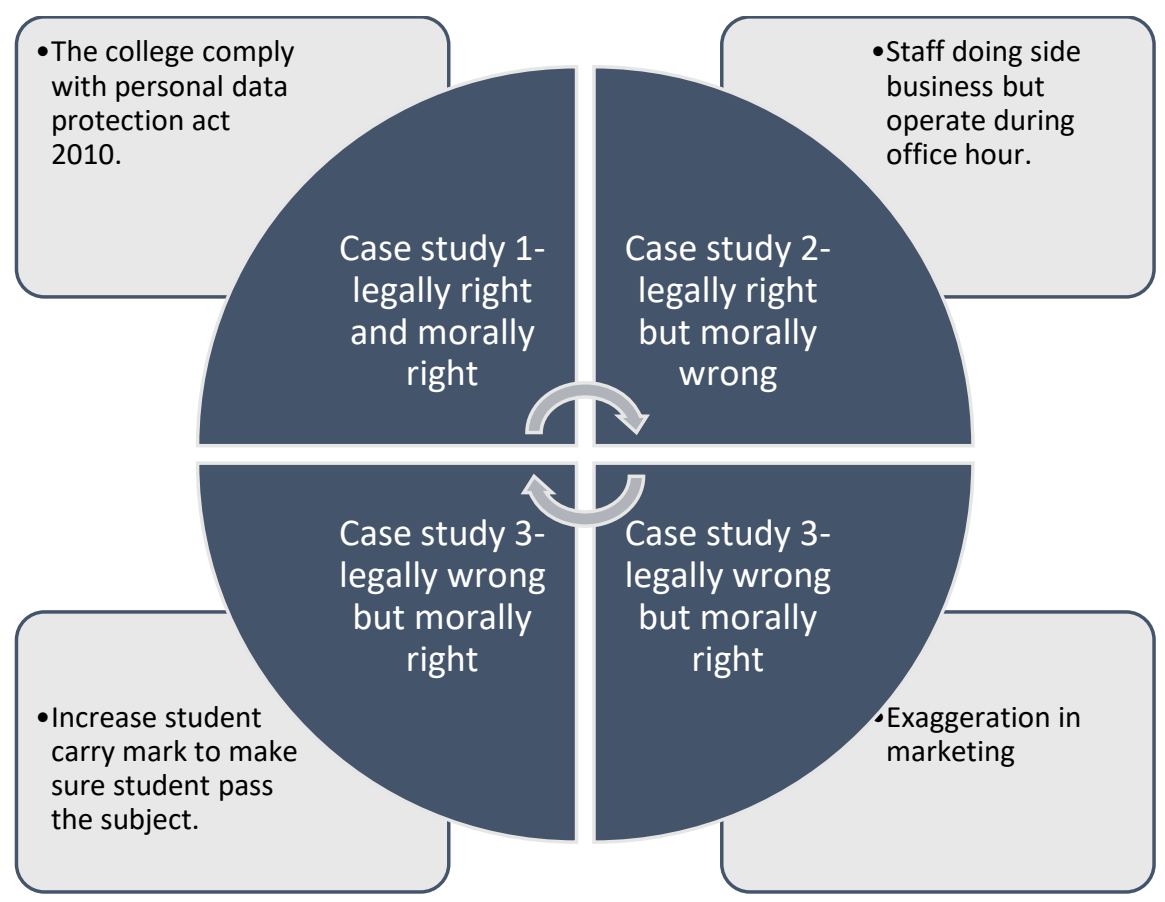

Figure 1. Case study component

This case study will review ethical values, moralism and integrity of a private college located in Kuantan based on the ethical principles. The evaluation conducted was based on semi structured interview conduct toward college staffs and students. The college has around 294 academic and support staff and run a various program from diploma to master program.

There are three objectives for the case study:

i. To analyze the ethical behavior and cases in four different ethical component setups;

ii. To relate the ethical cases with ethical principle;

iii. To review other ethical principle that counter the ethical cases

\section{LITERATURE REVIEW}

\section{Basic Principle of Ethics and Business}

Ethics is the study of morality which is defined as a rule that an individual or a group of people has about what is good or evil, or right or wrong. In business perspective, ethics has been seen as a moral standard that measures a business, institution and organization's behavior (Trevino \& Weaver, 2013). There are three types of ethical issues that are normally concerned in a business, which are systemic, corporate and individual. Within where a business organization operate, systemic ethical issue normally will question an organization's economic system, legal, politic and social. Corporate ethical issue will question a particular organization's actions, impact, climate, culture and policies. Apart from that, individual ethical issue will raise a question about a specific personnel character, behavior and decision (Trevino $\&$ Weaver, 2013).

\section{Utilitarian Principle}

Utilitarianism promote any policies or actions to be judged on the basis of the cost and benefits of the actions towards society. From the list of the utility alternative in any situation, the greatest utility will be considered as the only moral right action. Some of the famous utilitarian theorists are Jeremey Bentham; Bentham's Theory of Legislation (1932) and John Stuart Mill; Utilitarianism (1863) (Byars \& Stanberry, 2018).

Utilitarian focuses on any human actions or policies created on whether or not it should be decided on the weight of the cost and benefit that will impact the society. The principle assumes that the course of action chosen could be determined quantitatively, adding in factors that could benefit and counter any harm from the actions. According to the utilitarianism principles, the outcome or actions chosen should be the one with the greatest use or utility compared to the other alternatives (Velasquez, 2012).

There are also some critics on the utilitarian principle which states that not all values can be measured as utilitarian's consider monetary and common sense can measure everything. Critics argue that right and justice cannot be assessed 
based on monetary value and that not everything could be calculated by mathematics as human beings are complex (Ogan, 2019).

An alternative version of utilitarian called rule-utilitarianism which is to counter the objection on right and justice principle. The concept of rule utilitarianism is by limiting the utilitarian analysis to only by evaluating the moral rule. By doing so one is supposed to question whether the action chosen or taken is the correct moral rules that everyone should adhere to (Harsansyi, 1985).

\section{Kant and Moral Right Principle}

The concept of right can be defined as an individual's consent to do something. Right concept can be divided into two types which are legal right and moral right. Legal right is a consent from a legal system that empowers a person to act in a specific way towards others and vice versa. Another one is moral right where right that been accepted in the society which follow the norm of virtue of human beings (Byars et al., 2018).

Moral right can be divided into three categories. First, negative rights are defined as a terms of the duties others have not to interfere with such as human privacy. Negative rights require others leave an individual alone. On other hand positive rights was when others have a duty not only to refrain from interference, but also to provide you with what you need to pursue your interests for example right for food, right for life and right for good health care. Thus positive rights require others individual help for those who need. Lastly Contractual or special rights requires an individual to keep their agreements by creating a by specific agreement and conferring only to the parties involved. This would require publicly accepting the rules on what constitutes the agreements and what obligations the agreements should impose. This right underlie the special rights and duties imposed by accepting a position or role in an institution or organization.

Kant and moral right principle refer to an individual's interest in general which cannot be halt and should be left equally free. The interest should be a right and the interest need to stay rational and free. The first formulation of Kant's categorical imperative say that as human beings, we should do something only if we are able to accept it if other people were to do the act to us. This requires universalizability and reversibility consideration. Meanwhile The second formulation of Kant categorical imperative suggests that individuals should never use people only as a means to their ends, but always treat them as they freely and rationally consent to be treated and help them pursue their freely and rationally chosen ends. This was based on the idea that humans have a dignity that makes them different from mere objects.

Critiques towards Kant principle mention that this principal is imperative and unclear. Kant's definition of right is really subjective which can bring to conflict and Kant's principle cannot address such conflict. Besides that, Kant's principle can easily entail in moral judgment that are mistaken.

\section{Libertarian Principle}

Libertarian philosophy asserted that freedom is necessarily good when it contacts with human constraint and all constraint placed by others are necessarily evil except when needed to prevent intrusion from larger human constraint. Robert Nozick in 1974 said that the only moral right is the negative right to freedom and the right to freedom require social welfare program that need to be found by eliminate taxes, freedom of contract, free market and private property (Trundle, 2012). Justice can be divided into three categories which are distributive justice, retributive justice and compensatory justice.

Distributive justice requires the just distribution of burden and benefit. Six principle in distributive justice are fundamental which distribute benefits and burdens equally to equals and unequally to unequal's. Egalitarian states that anything needs to be distribute equally to everyone. Next, Capitalist principle that distribute according to contribution. Socialist principle said anything need to be distribute according to need and ability. Distribution by free choices is the principle of libertarian which related to distribution justice concept. Lastly principle of raws where distribution by equal liberty, equal opportunity and need of disadvantaged where the principle that support the principle of distributive justice (Velasquez, 2012).

Retributive justice required the just imposition of punishment and penalties. This reflect to action that require fairness when blaming or punishing persons for doing wrong. Lastly compensatory justice requires just compensation for wrong and justice. This related individual fairness when restoring to a person what the person lost when he or she was wronged by someone else.

\section{Ethics of Care}

Ethics of care emphasize that ethics should not be impartial and must be nurturing and preserving concrete value of relationship. The ethics of care falls under the normative ethical theory which states that moral action centers on interpersonal relationships and views the act of care or compassion as a virtue. Ethics of care is one of a cluster of normative ethical theories that were developed by feminists in the second half of the twentieth century. Caring is not detached but an engrossed "caring for" a person. Meanwhile relationships are not valuable when characterized by 
domination, oppression, harm, hatred, violence, disrespect, viciousness, injustice or exploitation. The demand of caring and of justice can conflict should be resolved in way that do not betray our voluntary commitment to others and relationship with them. In conclusion ethic of care is an ethic that required caring for the strong wellbeing particular person with whom we have valuable close relationship, particularly those dependent on us.

There are some critics on ethic of care which it can degenerate into favoritism. Besides that, it will lead to "burnout" which will acknowledge the need of caregiver to care (Jeurissen \& Rijst, 2007). Response to stand the principle are first conflicting moral demand are an inherent characteristic of moral choices. Second defend are adequate understanding of ethic of care will acknowledge the need of the caregiver to care of him or herself.

\section{.Moral Virtue Principle}

Aristotle in his book Nicomachean Ethics in 1566 said that virtue is a habit that enable a person to respond by habitually choosing the mean between extremes in emotion and action. Aquinas in his writing of Summa Theologica in 1217 in general said virtues are habit that enable a person to live reasonably in this world and be united with God in the next. Maclntyre in his book After Virtue in 1981 define virtue as disposition that enable a person to achieve the good at which human "practice" aim. Lastly Pincoffs in 1971 said that virtue are dispositions we use when choosing between persons or potential future selves (Byars et al., 2018; Salehi, Saeidinia, \& Aghaei, 2012). In summary all of these virtue theory is the theory that aim of the moral life is to develop those general dispositions called moral virtues, and to exercise and exhibit them in many situations that human life sets before us. There are some virtue theory claims related to virtues, action and institutions. First we should exercise, exhibit and develop the virtues. Next, we should avoid exercise, exhibiting and developing vices. And lastly institution should instill virtues not vices. Some critics toward virtue theories are inconsistent with psychology which showed that behavior is determined by the external situation, not moral character. Defender of this theories stress that moral character determines behavior in a person's familiar environment and recent psychology shows behavior is determined by one's moral identity which includes one's virtues and vices.

\section{METHODOLOGY}

The semi structured interview was held to gather experience and perspective of the college staff toward ethics, morality and integrity from college staff and students. The interviews were all recorded and transcribed. The case study was then classified into four different dimensions which are (i) legally right, morally right, (ii) legally right, morally wrong, (iii) legally wrong, morally right, and (iv) legally wrong, morally wrong as shown in Figure 1 . The best-case study from each dimension then will be selected and discussed from a theoretical perspective.

The research is a qualitative research method which is based on unquantifiable or non-numerical aspect for example opinion, or feeling. Research design is based on exploratory case study research design. The aim of this study is to explore business ethics in a private university environment without attempt to find-conclusive answer to research objectives. Semi structured interviews were conducted. The minimum 20 sample size is set as nature of study are based on grounded theory where non-probability data sampling is used. To make sure the result is deciding for the private institution, the sample was collected from staff with more than 5 years experience in the private institution and institution final year student.

\section{FINDING AND DISCUSSION}

The selected private institutions are facing a big challenge as they manage to upgrade their status. As the institution status and name has been changed, their mission, vision, scope, and responsibilities are also changing 360 degrees. Furthermore, before this, the institution once related to management fraud case and been a national issue and discussed in parliament. Thus by rebranding and upgrading their status, ethical issues are one of their primary focus, as they do not want the negative past issue to overshadow the institution achievement. This section will only discuss preliminary findings on the business ethic principle that can relate with each cases without commenting on whether the action taken was ethically right or wrong.

\section{Legal Right and Morally Right Case Study}

Personal data is any information that relates to an identified or identifiable living individual. Different pieces of information, which are collected can lead to the identification of a particular person and constitutes personal data. The purpose of personal data protection is to secure the essential rights and freedom of an individual that is identified with that information. On other hand, securing individual information it is conceivable to guarantee that people's rights and freedom are not violated. For example, incorrect processing of personal data, might bring about a situation where an individual is overlooked for a job opportunity or, even worse, loses his/her current job. Next, personal data guidelines are essential for guaranteeing and customer friendly toward provision of service. Personal data protection can create a circumstance, where, for instance, personal data cannot be sold to any party and thus an individual has a greater control over who makes him an offer and what kind of offer is being made.

According to the Personal Data Protection Act 2010, there are four main policies namely data collection, sharing and use of data, application of the privacy policy and change or amendment. The college will not gather any customer identifiable personal information except for information given itself by the customer through message or email. When a customer provides personal identifiable information, the data will be shared when necessary, with the Malaysian 
government, government authorities, government agencies and other relevant authorities for a reason to serve customer in the most competent and effective manner only. Other than that, the information also may be used by the college for the purpose of handling complaint, registration, internal audit, audit by relevant authorities and other matter involve the college. The privacy policy only applicable only on the college and there may a different and additional policy on different department or faculty. Customer are advised to check regularly as the college can make a change or amendment toward the policy.

Every individual should maintain their right regardless of their skin color, race and religion. The college should protect a student's personal data given to the college for academic purpose and the college has a moral obligation to use their student's data only for academic and internal purposes only. This case is related to the concept of right and duty. Right in general is an individual's entitlement to something and in this case, it is the student's right to know how their personal information that has been given to the college has been utilized. Specifically, this case can be related by contractual right and duties. This principle is also called special obligation or special right and duties. Contractual right and duties principle are defined as the limited right and correlative duties that arise when one person enters an agreement with another person. Student acquires a contractual right to whatever the college has promised. This can benefit the collage operation. Beside that the college has a contractual duty to perform as what it has promised. This to make sure there is no breach on their client personal data to be manipulate by third party organization and monetary services.

For further discussion, we consider the cases if the college is not sensitive to take care of the student's personal data. The college may sell their student's data for example, student email to third party companies. The third party company will have used the student email to blast their product promotion without the student consent to receive the promotion. First let's recall that most private institution in Malaysia struggle to collect fund for their operation. Thus for this situation, the collage action may have related to utilitarian's principle where they consider the benefit of money to sustain their business by cost they have to breach their student information that not give any damaged to the student a long their only get spam with a lot of promotional advertisement only.

\section{Legal Right and Morally Wrong Case Study}

For this section, the selected case are staff doing side business but operate during office hour. First, we cross check with the law either someone who already work with an organization can engage in other business or trade. Based on Malaysia Bar council for example, section 12.01. (2) said that; 'An Advocate and Solicitor who is a legal assistant may engage on a part-time basis in a business or trade that is in the opinion of the Bar Council not incompatible with the dignity of the legal profession, provided that it does not infringe his/her full-time employment by an Advocate and Solicitor or a firm of Advocates and Solicitors in accordance with section 30(1)(b) of the Legal Profession Act 1976.' (The Malaysia Bar council, 2014). Based on that policy there is no restriction for a person to register and conduct a side business. It just the matter of how the personal responsibility toward their real job.

In this case some student reported during academic section, there are some stuff promoting and sell their side business product during class. Morally, this action is considered wrong because the staff should not mix their full time working with their business. Them should maintain their professionalism as academician and smart to manage their time. It is not wrong to promote their side business product or service to co-worker and student but it morally wrong to do it during class section as they are being paid to teach not selling or do other things.

Next will be discuss is on ethical principal point of view on staff doing side business but operate during office hour. First, it is not wrong to own a side business but it is considered morally wrong when an individual is more focused on their side business when they promote or doing the business during their main working hours. For this case this action can related by libertarianism principle on justice of freedom. There is no particular way of distributing goods can be said to be just or unjust apart from the free choices individual make. Any distribution of benefits and burden is just if it is the result of individuals freely choosing to exchange with each other the goods each person already own. Related to the case, for what the staff chooses to do for example selling cookies. The staff should be allowed to sell the cookies anywhere and anytime as they want to due to their right. This principle stress on every person has a right to freedom coercion that takes priority over all other values and rights.

For further discussion, to counter the freedom of act for this scene, the person should consider the principle of moral virtue. From the perspective of virtue ethics, the lecture should question itself either they act is morally toward their student and their job? Logically the good human being should do their jobs as what they agreed to be pay. In this cases, the instructor has already agreed by signing the work contract that they will fulfill the student credit hour by teaching and discuss on the related subject. Thus it is wrong to taking advantage as maybe the student feels attached when their lecture promoting something as they maybe need to show some support to get a higher mark. Thus virtues are disposition that enable a person to achieve the good at which human 'practice' aim is the most suitable moral virtue theory for the person to consider before act for this scenario. 


\section{Legal Wrong and Morally Right Case Study}

For this section we will discuss on case study that both are legally and morally wrong. Based on interviews, most lecturer faces a dilemma related to students' grade. Most of them admit that they have added at least one mark to increase a student's carry mark to make sure that the student passes the subject they teach. This situation happens normally when some student received a marginal pass grade. It's always a question for the lecture; if one of your students got a marginal passing grade, would they let him or her pass?

There is a huge debate about this problem, and it depends on the situation at that time. But in general, this kind of act is legally wrong because to pass, the student should obtain marks more than the college's passing grade. The lecture should follow the marking shame provided by the institution. It is also morally wrong if the lecturer passed the student because of favoritism or empathy, but the student should fail as the student has missed classes and do not submit their assignments.

For this case, the situation was when the lecture teaches a core subject. It depending on the course being lectured. For example, a language course, or a literature course are different from a Calculus course or Mathematics or Physics course. Calculus course is normally considered as difficult, and for this type of course, in the authors' opinion, marks can be added to students obtaining a marginal pass to assist them to pass the course. Attitude of students during the whole semester, his or her interest in learning in the class and the attention given to the professor on his or her lectures and practical classes during the semester should also be considered in assisting students with marginal pass to pass the course.

It is related to the first factor that is the difficulty level of the course such as calculus. If the student has given full commitment during class thus its morally okay to help the student due to their effort. Lecture judgment also effected by the student result on partial tests carried out during the semester and the level accomplished of all of the students' duties and the number of times that the student disapproved other classes on the same or related subject. On other hand, another factor that may affect lecture judgment are influence such act is the year where the student is. Is not the same if the student is in his or her first year of his or her career or the student is close to be graduated?

In business ethic point of view, the case was when the lecture increase student carry mark to make sure student pass the subject. As elaborate earlier on previous paragraph above we will view this case on student situation supposedly need to be help. The most suitable principle related with the case is the ethic of care. Ethic of care need to be impartial, unlike conventional ethical principle which assume ethic has to be impartial. This principle stress on someone should be care for those dependent on and related to us. For case study on certain situation the student mostly dependent on care from the lecture for example the student already on final semester and to pass the paper is necessary which fail to do so the student need to extend their study time which related to their financial problem. This point is not to agree that it okay to bypass the academic marking shame but just a discussion on what an ethical philosophy that related to the case without arguing with another theory.

For further discussion, the act still consider as wrong as the lecture by purpose increase some student mark. Kant and moral right stress that never use people only as a means to your ends, but always treat them as they freely and rationally consent to be treated and help them pursue their freely and rationally chosen ends. Thus the student should accept whatever marks that their get as they entitle those mark. Those mark reflect the student understanding and hard work toward the course. By concept of all human must treated equally, it is not fair to other student that work 200 percent to pass the subject but when some get marginal mark they easily can pass the subject.

\section{Legal Wrong and Morally Wrong Case Study}

The Advertising Standards Authority Malaysia in an independent organization responsible for ensuring that the system is uphold for the public's best interest. Due to this reason, advertisements by companies or organizations should not abuse their platform by abusing consumer's trust by using incorrect data or by exaggerating information in their marketing (Standards \& Damansara, 2014).

As private universities mostly relies on student's enrollment to sustain their operations, they should not take advantage to exaggerate in their marketing to motivate students to join their college. This act is clearly legally and morally wrong. In most cases, the marketing team often give an incomplete information about the program offered to students especially on student loan and scholarship. The worst case is when some of the students have been approached to enter the program and there is a promise to offer student loans but all is done verbally. When the student is not able to obtain the loan, nothing can be done as the discussions are done verbally.

For the case of exaggeration in marketing in business ethic principle, this kind of activity is unacceptable but in ethical principle's point of view, there is some principle that supports this kind of activity. The most suitable principle to relate with this kind of case is Utilitarianism principle. Utilitarian promote actions should be evaluated on the basis of the benefit and cost they produced for everyone in society. The academic institution is the place to nature education to society. On other hand the college hardly depend on the student enrollment to sustain the business. Thus, it may be considered okay 
for the college to a litter bit of exaggeration in their marketing as long their business can sustain and provide education services to all the student enroll.

In father discussion this case is clearly wrong by legal and moral because the collage has intention to cheat on their customer to get more volume neglect what reason they give. As principle of justice and fairness clearly object this kind of action as freedom from human constraint is necessarily good and that all constraints imposed by others are necessarily evil except when needed to prevent the imposition of greater human constraints. The student has their own right to bring this matter to authority if they feel that been manipulated by the collaged advertisement. On other hand also the collage also has right to stand their act on court in the name of right and justice. But by the nature of virtue principle the collage management already know this kind of action is morally wrong as they have intention to exaggerate in their advertisement to get more student.

\section{CONCLUSION AND IMPLICATIONS}

In conclusion, ethical behavior and organization sustainability is related to one and another. From the four different cases of legally and morally different setup, there are related ethical principles that we can related with that act. In business the practice ethical principle uses can justify some action that maybe in general the society see it as wrong, but justification can prove it differently. For example, the principle of utilitarian approached in some moral decision making in some make it can neglect the morally wrong action as it considers will bring impact toward cost of the organization if been abolished. For further research it is recommend that the case study is analyzed deeper using proper research design and statistical analysis. Other than that, integration between various approached need to be study toward moral evaluation.

The implication that may happen to college organization if they take action to improve their organization business ethic based on the cases disused are first the college employee will not feel okay to by-pass established protocols in order to be more efficient or effective at work. Besides that, the college will try to do business that will not deceive customers. The college employee will avoid conflicts of interest by not advancing their own interests over those of the company. Next the college management will improve awareness and protection of the claims and rights of people in the community served. Other than that, the college management will provide training programs that effectively communicate ethical standards and policies. Lastly, the ethics committee or team that deals with ethical issues in the organization will be created and code of ethics and SOP regarding ethical issue will be created.

\section{REFERENCES}

Alan Lovell, \& Colin Fisher. (2010). Business Ethics and Values: Individual, Corporate and International Perspectives (3rd Edition). Pearson. Retrieved from https://www.pearson.com/us/higher-education/program/Fisher-BusinessEthics-and-Values-Individual-Corporate-and-International-Perspectives-3rd-Edition/PGM315136.html

Byars, S. M., \& Stanberry, K. (2018). Business ethics. OpenStax. Retrieved from https://open.umn.edu/opentextbooks/textbooks/business-ethics-2018

Harsanyi, J. (1985). Rule Utilitarianism, Equality, and Justice. Social Philosophy and Policy, 2(2), 115-127. doi:10.1017/S026505250000323X

Jeurissen, R. (Ronald J. M., \& Rijst, M. van der. (2007). Ethics \& business. Koninklijke Van Gorcum. Retrieved from https://books.google.com.my/books/about/Ethics_Business.html?id=reio7fsiTBEC\&redir_esc=y

Laws of Malaysia. (2015). Private Higher Educational Institutions Act 1996. Attorney General's Chambers of Malaysia, (December), 1-89. Retrieved from http://www.agc.gov.my/agcportal/uploads/files/Publications/LOM/EN/Act 555 - Private Higher Educational Institutions Act 1996 (As at 1 December 2015).pdf

Ministry of Education Malaysia. (2015). Executive Summary Malaysia Education Blueprint 2015-2025 (Higher Education). Ministry of Education Malaysia, 2025, 40. https://doi.org/10.5923/j.ijis.20120206.05

Mohd Azrone Sarabatin; Mohd Iskandar Ibrahim: Mohd Nasaruddin Parzi. (2019). PTPTN kesan IPTS tipu dokumen. Retrieved June 19, 2020, from https://www.bharian.com.my/berita/nasional/2019/03/545190/ptptn-kesan-iptstipu-dokumen

Mohd Pilus, F. A., \& Mahmood, F. (2019). IPTS Tipu PTPTN. Retrieved June 29, 2020, from https://www.hmetro.com.my/mutakhir/2019/03/437559/ipts-tipu-ptptn

Ogan, T. V. (2018). John Stuart Mill's Utilitarianism: A Critique. International Journal of Peace and Conflict Studies, 5 , 65-76.

Salehi, M., Saeidinia, M., \& Aghaei, M. (2012). Business Ethics, 2(1), 1-5. https://doi.org/10.1111/1467-9973.00225

Standards, A., \& Damansara, O. J. (2014). MALAYSIAN CODE OF ADVERTISING PRACTICE.

The Malaysia Bar council. (2014). The Malaysian Bar - 12.01. Engagement in other business or trade. Retrieved May 24, 2019, from http://www.malaysianbar.org.my/bc_rulings/12.01._engagement_in_other_business_or_trade.html

Trevino, L. K., \& Weaver, G. R. (2013). Business ethics. Business Ethics Quarterly, 4(2), $113-128$. https://doi.org/10.5840/10.2307/3857484

Trundle, R. C. (2012). Business, Ethics, and Business Ethics. Thought, 66(3), 297-309. https://doi.org/10.5840/thought199166326

Velasquez, M. G. (2012). Business Ethics: Concepts and Cases: 7th Edition. Pearson, New Jersey.

Wan, C. Da, Sirat, M., \& Razak, D. A. (2018). Education in Malaysia Towards a Developed Nation. Yusof Ishak Institute, 
20. Retrieved from https://www.iseas.edu.sg/images/pdf/ISEASEWP2018-4Wan.pdf

\section{AUTHORS' BIOGRAPHY}

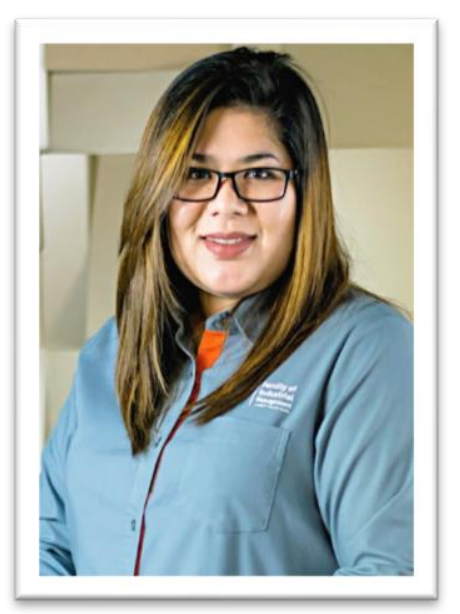

Dr. Diyana Kamarudin is currently the Head of Research Cluster for Marketing and Entrepreneurship, and was also appointed as the SME for Research Methodology at the Institute of Postgraduate Studies, UMP. She is currently on the editorial board for the Asian Journal of Instruction, and the International Journal of Innovation and Industrial Revolution (IJIREV).

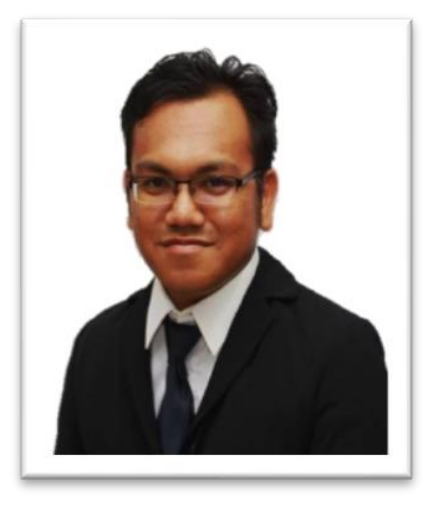

Haziman Zakaria is an entrepreneur and part time lecturer at various institutions. He is currently very active in business and has an interest in Business Ethics. He has also participated in various conferences and co author a module on entrepreneurship.

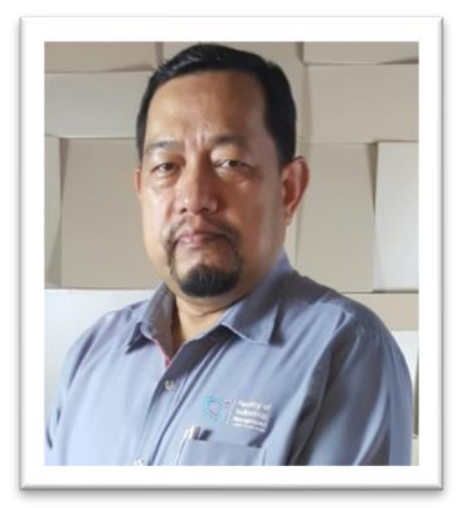

Azizan Azit is a lecturer at University Malaysia Pahang, teaching entrepreneurship courses. He has been teaching for more than 20 years and is active with entrepreneurial programmes. 